\title{
The comparative analysis of TL-SDI values, within the area of administrative posts in the municipality of oecusse
}

\author{
Sri Endang Purwatiningsih ${ }^{1, *}$, Sukamdi Sukamdi², and Sri Rum Giyarsih ${ }^{3}$ \\ ${ }^{1}$ Population Studies, Post Graduate School, Universitas Gadjah Mada, Indonesia. \\ ${ }^{2}$ Migration and Population Development, Post Graduate School, Universitas Gadjah Mada, Indonesia. \\ ${ }^{3}$ Geography and Population Development, Post Graduate Post Graduate School, Universitas Gadjah Mada, Indonesia.
}

\begin{abstract}
This research aims to analyze and compare value of TL-SDI, within area of administrative posts in the municipality of Oecusse related to internal migration status. This study uses a quantitative approach based on the CPH-TL 2015 and TL- SLS 2014 data, using lifetime migration that applied on the concept of TL-SDI, SCI, EcCI, and EnCI within area of administrative posts in the municipality of Oecusse. Analysis comparison of TL-SDI uses CSpro, SPSS, and Excel, tools with the amount of sustainable development indexes is the percentage of migration rates. The results of this study have produced three (3) type of specific values of TL-SDI, rejected the hypothesis that there is no significance the values of TL-SDI between the migrant population and the non-migrant population. The TL-SDI values in migrant populations are higher than in non-migrant populations. TL-SDI values in each region can be used as an evaluation of the results of development so far has been running and can be used as regional planning material, especially for indigenous people or migrants who come to the region.
\end{abstract}

Keywords: Economic Composite Index (EcCI), Environment Composite Index (EnCI), Life-time migration, Social Composite Index (SCI), Timor-Leste Sustainable Development Index (TL-SDI).

\section{Introduction}

Timor-Leste is one member of a small- dimensional island nation (SIDS) with a small population in Pacific Region and the UN members state that a sustainable development policy in Agenda 2030 in 2015 [1-3] has been ratified. In this 2030 agenda document there are development objectives complete with indicators that can be used to measure the results and achievements of development in a country $[4,5]$. Timor-Leste conducted a population and housing census in 2004, 2010 and 2015 , and has planned to return a population census in 2020 [6]. The population and housing census program has used the measurement standards set by the UNDESA Institute as stated in the document manual that is the 2008 edition of the population and housing census manual $[7,8]$.

The results of the population and housing census in the country of Timor-Leste in 2015 recorded 1183643 inhabitants, 204597 households spread over 13 municipalities, 65 post administrative, and 465 sucos, including population and household on area Municipality of Oecusse [9]. Based on RDTL government policy Law No: 3/2014 states that the municipality of Oecusse is part of the Special Administrative Region of Oecusse Atauro (SAROA) as a special area for social economic development and development including: development of clean drinking water infrastructure, energy sources electricity, airport and seaport to facilitate accessibility to the Oecusse enclave area and Atauro island [10-12]. The results of this population census can be used statistically to compile the index of sustainable development in the future that can be used to plan and evaluate development that has taken place in the past years.

This research aims to compare the value of TL-SDI in the municipality of Oecusse that has been built in previous research dissertation on a measurement index that can be used to measure the achievement of sustainable development in Timor-Leste country [13]. Consider with specific condition, Timor- Leste with a small island area, has a small population [14] using development indicators as stated in the SDGs document that has ratified by the country of Timor-Leste. This article intends to resolve research problems for which there has not been any measure of achieving sustainable development in the country of Timor-Leste that has been tested, effective and efficient. For this reason, the Timor-Leste Sustainable Development Index (TL-SDI) was built with the aim of measuring development planning and achievement using three integrated dimensions covering social, economic and environmental dimensions, including six (6) goals, eleven (11) indicators, and fourteen (14) variables. Timor-Leste Sustainable Development Index (TL-SDI) itself consists of a social composite index (SCI), an economic composite index (EcCI) and an environmental composite index (EnCI) by processing data TL-CPH 2015 data and TL-SLS 2014. In previous research IOM has produced a concept that people who migrate can

\footnotetext{
* Corresponding author: endangvong@gmail.com
} 
encourage sustainable development for the better [15]. Thus, this research on the Timor- Leste Sustainable Development Index (TL-SDI) uses the concepts that have been produced by IOM so that the Timor-Leste Sustainable Development Index (TL-SDI) value can be generated by distinguishing between migrant and nonmigrant populations.

\section{Data and method}

Some previous researchers have conducted research in several countries that emphasize the problem of sustainable development, but they did an evaluation of development focus on just one particular dimension; for example in Spain it only measures welfare index [16], social inclusive development index for European countries [17], for socio and culture sustainability [18] or only measures environmental dimension [19], all of these studies refer to the formation of composite index values. Other researchers have examined several indicators of sustainable development in the industrial sector [20], while Cuaresma and Lutz [21] have examined the issue of sustainable development in poor countries to illustrate the characteristics and habits of populations that focus on age, sex, education level, housing, and living standards. This study may be more in line with previous researchers from China [22] who have examined sustainable development that emphasizes three dimensions namely social equity, quality economic growth and protection of the environment where residents live.

Planning and evaluation of development outcomes can be carried out by maximizing the results of a population and housing census that has been carried out in the country of Timor-Leste. Overall, the purpose of this study is to establish TL-SDI values that are complete and complex, including SCI, EcCI and EnCI, which can be used to plan and evaluate the development process that is appropriate for the territory of TimorLeste. Thus TL-SDI processes data sourced from TLCPH 2015 and TL-SLS 2014. Specifically this article is a small part of the results of the development of TimorLeste's sustainable development index value, this article aims to compare the value of TL-SDI without differentiating the status of population migration, in non-migrant populations, and in migrants in the municipality of Oecusse as enclave areas. Thus, the municipality of Oecusse have TL-SDI value can be used as a material for planning and evaluating the development that exists in municipality of Oecusse as part of the territory and population of Timor-Leste. The TL-SDI municipality of Oecusse is in three major parts: 1) without differentiating the status of population migration, 2) in the non-migrant population, and 3) in the migrant population. This research as part of national TL-SDI, but in this publication, researcher can compare the TL-SDI value including four (4) administrative posts and in municipality of Oecusse only. So that a specific value for each area will be obtained based on the migration status of its population. Thus, this study will produce TL-SDI values at each regional level by distinguishing the internal migration status of its population.

\subsection{Sustainable development}

Recognition of the need for sustainable development related to population dynamics has been declared since the Development and Environment Conference by the UNCED Institute in Rio Janeiro in 1992 [23], then reaffirmed in the ICPD agreement which was adopted by 179 countries in the year 1994 in Cairo Egypt in the third part there is an explanation of the interrelationship between the population, the sustainability of economic growth and sustainable development [24]. The results of this research further emphasized that population development oriented to the new understanding that reflects cross-sectoral relations, within dimensions of sustainability to improves the quality of life of the population for the current generation needs while still paying attention while still considering the ability and the needs of future generations.

The reality that has taken place to date has proven the phenomenon in society that sustainable development is an integrated economic, social, and environmental dimension to one another. This research produces the value of IPB-TL which is a measurement of sustainable development with integrated economic, socio-cultural and environmental dimensions and it is hoped that the value of IPB-TL can be utilized for planning and evaluating the development process by policy makers in the development process in their respective region [25, 26].

Meanwhile, Herrmann [27] and Rodrigues [20] defines sustainable development as follows: sustainable development is a tool to ensure human welfare, which implies quality and equality in the development of wellmanaged economic, socio-cultural and environmental resources, harmonization with a dynamic balance for improving the quality of life for all residents in all countries. Furthermore, the development of infrastructure and population policies must promote the reduction of unsustainable consumption behavior, so that the needs of the present generation can be met without reducing the ability to meet the needs of future generations [20, 27, 28].

Sustainable development focuses on three values including: (1) social justice by eliminating poverty, hunger, disease and violence, reducing literacy, universal educational opportunities, (2) economic welfare with economic growth and providing employment for all residents and ( 3 ) the response to environmental preservation which is a response to current and future consumption of the population, climate change and environmental damage caused by human activities, these three values make complex interactions [29, 30]. Another opinion states that the concept of sustainable development not only includes three (3) economic, socio-cultural and environmental dimensions, but Yang [31] has provided one additional dimension which is to be four (4) dimensions namely energy, natural resources, sustainability of the transportation system, and socio-economic balance [31]. 
Some theories also emphasize that sustainable development has coverage not only on limitations, but also pay attention to the potential that is accessible, spatial accessibility. Coverage of physical conditions and natural laws that do not change, changes in technology, culture, values and aspirations, and sustainability of a society must follow sustainability that changes either continuous change, corresponding change, or strong or extreme changes in development. Bossel (1999) has defined sustainable development as a dynamic concept, connected in a complex unit system of several aspects including economic, social, political, psychological, and natural environmental [32].

\subsubsection{Relationship of internal migration and sustainable development.}

The concept of migration is an inseparable part of sustainable development [33], thus all migration and population development activities must pay attention to and in accordance with the goals and objectives of sustainable development.

In the document agenda 2030 on sustainable development paragraph 29th, it is explained that migration and migrants can make a positive contribution to the development for the destination and origin areas in the form of inclusive economic growth. Thus, the process of migration and migrants must be treated humanely and respectfully, considering, and respecting human rights, regardless of their migration status [34]. Various studies have proven that internal migration of the population has contributed to the growth of population in urban areas and the process of urbanization, the population is looking for better social and economic and environmental opportunities. However, Awumbila [35] due to the increasing capacity of urban areas to serve migrants by providing employment, access to land, limited basic facilities.

In positioning the relationship between migration and development Haas [36], two different perspectives have been established, namely: (1) migration as an optimistic development has a neo-classical functionalist and ideology, modernization, there is a transfer of movement from developed countries (north) to the country developing (south), providing intelligence (brain gain), tend to be more parallel, remittances sent are used as investments and there are changes in development, migration in small amounts. In the opposite position (2) see migration as a pessimistic development having structural list characteristics and neo-Marxist ideology, des- integration, there is a transfer of movement from developing countries (south) to developed countries (north), drying intelligence (brain drain), tend to be gaps, remittances sent are used as consumption and there is a large number of dependencies, migration. Population migration and sustainable development are developments with a new paradigm of neo- liberalism Harris [37] and Rodriguez [20]. As Voss [38] in the social structure theory proposed by Galpin's, 1915; Mowrer, 1938, Park 1929 and Hawley's, 1950 that migration is related to changes in the social structure of society, where people are increasingly heterogeneous in their environmental patterns and processes.

\subsubsection{Measuring of sustainable development}

Correspondent to Hawkins [39] that sustainable development is one of the four pillars in measuring the happiness index in the country of Butan. Meanwhile Blancas [40] states that the sustainable development index can be compiled using a composite index as an indicator of development by using multiplicative and alternative ranking techniques. Hamedani [41], argues that sustainable development can be evaluated using several models with quantitative statistics approaches and composite index development, more Brink and Colijn (2013) [42] stated that evaluation and planning of the construction of public facilities in an area can use the resulting composite index can be described using the "amoeba" model. This amoeba sustainable development model has an amoeba-like rotating pattern by integrating several indicators, where the outer portion of the circle is the highest sustainable development value. Likewise, on the contrary, one indicator is getting towards the center of the circle, so the value of sustainable development of the indicator is getting lower or not sustainable. Ameba model has advantages, because it can integrate many indicators and facilitate comparisons between components in achieving sustainable development in an area [41].

Several previous studies on the measurement of sustainable development are on several issues, including: measurement and evaluation of sustainable development using a composite index in the Greek North Aegean islands [43], the indicator building composite indicators TAI [44], integrated development testing model of sustainable development [45], and survey results on the Indonesian child welfare composite index [46].

\subsubsection{Measuring of internal migration.}

The definition of migration is migration of people on a spatial scale (migration of a population from one place where he used to live to a new place, in variations in distance of movement), and on a time scale (variations in length of residence permanently and not permanently) with regard to the point of origin, region transit and destination areas [7, 47-53]. Furthermore, modern migration has been defined as a permanent or semipermanent change of residence without restrictions on the distance of movement, carried out naturally or voluntarily, spatially across administrative boundaries, with patterns of internal migration and international migration, having a relationship with development sustainable, become a measurement tool for the progress of development on socio, economic and environmental [7, 48, 49, 54]. Migration is an illustration of living habits and rational human behavior and can be analyzed in the context of space and time [53, 55].

Measurement of population migration must pay attention to 4 (four) factors, namely: factors of origin, destination factors, migration barriers, and personal 
factors present in migrants themselves. With these four factors, the measurement of population migration can show the position of migrants as a factor of increasing population in the destination area and as a factor of reducing population around origin $[48,56]$. One measure of migration used in the results of a population census is a lifetime population migration. In the census implementation manual published by the UNDESA agency, it has set a lifetime migration as one of these measures of migration in a spatial and time context. In the migration time scale divided into classifications: permanent migration and non-permanent migration [57].

Qualifications for permanent migration are population movements calculated at the time of their census that more than 6 months have lived and intend to settle in the new location, where the new location (administrative area). This definition of internal migration relates to the concept of lifetime migration and place of birth. The concept of a lifetime migration used in this study is defined as population migration measured by differences in the administrative area of the birthplace and the enumeration site at the time of the population census, having lived at least 6 months before the census or intending to settle in the place where the respondent was enumerated [7, 51, 58]. Life- time migration that has been carried out by residents either individually or in groups, both on the scale of internal migration and international migration. International migration by residents from home countries, through international borders to other countries $[8,59]$.

This study uses a quantitative approach by testing the null hypothesis (Ho): the values of TL-SDI between migrant and non-migrant residents do not difference within administrative posts in the municipality of Oecusse. This study uses census data from residents who have experienced a lifetime migration, using quantitative approach. TL-SDI was built using the composite index method using three dimensions including social, economic, and environmental; six goals, eleventh indicators, fourteen variables, and two data sources: CHP- TL 2015 data and TL-SLS 2014 as shown in Table 1.

The statistical process for forming the TL-SDI value is as follows:

a. Recognize data structures from census 2015 data sources and poverty survey data TLSLS 2014.

b. Select SDGs Indicators: global and local (Table 1).

c. Build variables based on SDGs indicators (Table 1).

d. Form the proportion of indicators by migrant status and area.

e. Test the validity and reliability of selected variables.

f. Build value standards.

g. Calculate the standardization value of indicators (Table 2). h. Calculates the dimension composite index value (value of SCI, EcCI, EnCI).

i. Calculate the comparison of TL-SDI values using Excel ANOVA Single Factor for sixtyfive (65) administrative posts including administrative posts in area municipality of Oecusse (Table 3 and Table 4).

j. Calculates the SDI-TL index (Table 5 and Table 6).

\section{Results and discussions}

In accordance with the research procedure with a quantitative approach, the fourth step in the preparation of the TL-SDI has begins with the validity and reliability tests on the fourteen variables that have been selected and the number of samples $(n=249)$, using software SPSS17. This validity test aims to determine the level of validity of the variables that will be used by using Pearson product moment correlation test. The variable chosen to establish TL-SDI is declared valid and significant because the Pearson product moment correlation test results show the statistical correlation value is greater than the value of $r$ table, and the significance value (Sig 2-tailed) is smaller than 0.05 .

This reliability test is needed to see the consistency of data in the variables that make up the value of the TLSDI. The validity test results for fourteen variables of TL-SDI in the form of Alpha Cronbach's values equal 0.796 , that is greater than the standard value of 0.60 , its mean the data on fourteen variables is reliable and this research is feasible to proceed to another TL-SDI stage. The Timor-Leste Sustainable Development Index (TL$\mathrm{SDI}$ ) is a composite index of conditions of sustainable development in the population in the post administrative and municipal areas based on a combination of three SCI, EcCI and EnCI, which are analyzed using different migration statuses (migrants and non-migrants), and also without differentiating the status of migrants in the population of the region. The TL-SDI is important for evaluating and grouping post administrative analysis units in conditions of achieving sustainable development figures in separate of three SCI, EcCI and $\mathrm{EnCI}$, or in integrated composite indexes as TL-SDI. Referring to the previous research and research methods $[46,60,61]$, in this study the composite index of TLSDI for the country of Timor-Leste has a scale in five (5) groups namely:

a. Best with an indexof sustainable development ranging from $81-100$.

b. Better with an index of sustainable development ranging from $61-80$.

c. Favorable (good enough) with an index of sustainable development ranging from $41-60$.

d. Passable (bed) with an index of sustainable development ranging from $21-40$.

e. Poor (worse) with an index of sustainable development ranging from $0-20$. 
Table 1. Goals, indicators, data sources, dimension, and variables to measuring TL-SDI

\begin{tabular}{|c|c|c|c|c|c|c|}
\hline $\begin{array}{l}\text { No } \\
\text { Goals }\end{array}$ & Goals & $\begin{array}{c}\text { No } \\
\text { Indicator }\end{array}$ & $\begin{array}{l}\text { UN } \\
\text { Indicators } \\
\end{array}$ & $\begin{array}{c}\text { Data } \\
\text { Sources } \\
\end{array}$ & Dimension & Variabel of TL-SDI \\
\hline \multirow{5}{*}{ Goal 4 . } & \multirow{5}{*}{$\begin{array}{l}\text { Ensure inclusive } \\
\text { and equitable } \\
\text { quality education } \\
\text { and promote } \\
\text { lifelong leaming } \\
\text { opportunities for } \\
\text { all }\end{array}$} & \multirow{4}{*}{4.6} & \multirow{4}{*}{$\begin{array}{l}\text { Ensure that all youth and a substantial } \\
\text { proportion of adults, both men and } \\
\text { women, achieve literacy and numeracy, } \\
\text { until } 2030\end{array}$} & \multirow{4}{*}{$\begin{array}{l}\mathrm{CPH}-\mathrm{TL} \\
2015\end{array}$} & \multirow{5}{*}{$\begin{array}{l}\text { Social } \\
\text { dimension }\end{array}$} & $\begin{array}{l}\text { Proportion of population } 10 \text { years and over } \\
\text { literacy in Tetum }\end{array}$ \\
\hline & & & & & & \begin{tabular}{|l|}
$\begin{array}{l}\text { Proportion of population } 10 \text { years and } \\
\text { over literacy in Portuguese }\end{array}$ \\
\end{tabular} \\
\hline & & & & & & $\begin{array}{l}\text { Proportion of population } 10 \text { years and } \\
\text { over literacy in Bahasa Indonesia }\end{array}$ \\
\hline & & & & & & $\begin{array}{l}\text { Proportion of population } 10 \text { years and } \\
\text { over literacy in English }\end{array}$ \\
\hline & & 4.1 & $\begin{array}{l}\text { Ensure that all girls and boys } \\
\text { complete free, equitable and quality } \\
\text { primary and secondary education } \\
\text { leading to relevant and effective } \\
\text { learning outcomes, until } 2030\end{array}$ & $\begin{array}{l}\mathrm{CPH}-\mathrm{TL} \\
2015\end{array}$ & & \begin{tabular}{|l|} 
Proportion of population 12 years and \\
over have complated basic education. \\
Proportion of population $15-24$ years have \\
complated secondary education.
\end{tabular} \\
\hline Goal 1 & \begin{tabular}{|l} 
End poverty in all \\
its forms \\
everywhere
\end{tabular} & 1.1 & $\begin{array}{l}\text { Eradicate extreme poverty for all people } \\
\text { everywhere, currently measured as } \\
\text { people living on less than } \$ 1.25 \text { a day } \\
\text { until } 2030 \text {. } \\
\end{array}$ & \begin{tabular}{|l} 
TL-SLS \\
2014
\end{tabular} & \multirow{4}{*}{$\begin{array}{l}\text { Economic } \\
\text { dimension }\end{array}$} & $\begin{array}{l}\text { Proportion of population that living in Non- } \\
\text { poor household (with incme more than } \\
1.33 \$ \text { per capita per day) }\end{array}$ \\
\hline \multirow{3}{*}{ Goal 8.} & \multirow{3}{*}{$\begin{array}{l}\text { Promote } \\
\text { sustained, } \\
\text { inclusive and } \\
\text { sustainable } \\
\text { economic } \\
\text { growth, full and } \\
\text { productive } \\
\text { employment and } \\
\text { decent work for } \\
\text { all }\end{array}$} & 8.5 & $\begin{array}{l}\text { Achieve full and productive employment } \\
\text { and decent work for all women and men, } \\
\text { including for young people and persons } \\
\text { with disabilities, and equal pay for work of } \\
\text { equal value, until } 2030 \text {. }\end{array}$ & \multirow{3}{*}{$\begin{array}{l}\text { CPH-TL } \\
2015\end{array}$} & & \multirow{3}{*}{$\begin{array}{l}\text { Proportion of population } 15-59 \text { years, in } \\
\text { economic active, have worked status }\end{array}$} \\
\hline & & 8.6 & $\begin{array}{l}\text { Substantially reduce the proportion of } \\
\text { youth not in employment, education or } \\
\text { training, until } 2030\end{array}$ & & & \\
\hline & & 8.8 & $\begin{array}{l}\text { Protect labour rights and promote safe } \\
\text { and secure working environments for } \\
\text { all workers, including migrant workers, } \\
\text { in particular women migrants, and } \\
\text { those in precarious employment, } \\
\text { until } 2030 \text {. }\end{array}$ & & & \\
\hline \multirow{3}{*}{ Goal 11.} & \multirow{3}{*}{$\begin{array}{l}\text { Make cities and } \\
\text { human } \\
\text { settlements } \\
\text { inclusive, safe, } \\
\text { resilient and } \\
\text { sustainable }\end{array}$} & & Ensure access for all to adequate, safe & \multirow{7}{*}{$\begin{array}{c}\text { CPH-TL } \\
2015\end{array}$} & \multirow{7}{*}{$\begin{array}{l}\text { Enviromental } \\
\text { dimension }\end{array}$} & $\begin{array}{l}\text { Proportion of population that living in } \\
\text { household has sustainable home } \\
\text { ownership }\end{array}$ \\
\hline & & 11.1 & $\begin{array}{l}\text { and affordable housing and basic } \\
\text { services and upgrade slums, until } 2030\end{array}$ & & & $\begin{array}{l}\begin{array}{l}\text { Proportion of population that living in } \\
\text { household has sustainable liveable } \\
\text { homes }\end{array} \\
\end{array}$ \\
\hline & & 11.6 & $\begin{array}{l}\text { Reduce the adverse per capita } \\
\text { environmental impact of cities, } \\
\text { including by paying special attention to } \\
\text { air quality and municipal and other } \\
\text { waste management, until } 2030 \text {. } \\
\end{array}$ & & & \multirow{2}{*}{$\begin{array}{l}\text { Proportion of population that living in } \\
\text { household has sustainable sanitation } \\
\text { facilities. }\end{array}$} \\
\hline \multirow[t]{2}{*}{ Goal 6.} & \multirow{2}{*}{$\begin{array}{l}\text { Ensure } \\
\text { availability and } \\
\text { sustainable } \\
\text { management of } \\
\text { water and } \\
\text { sanitation for all }\end{array}$} & 6.1 & $\begin{array}{l}\text { Achieve access to adequate and } \\
\text { equitable sanitation and hygiene for all } \\
\text { and end open defecation, paying special } \\
\text { attention to the needs of women and } \\
\text { girls and those in vulnerable } \\
\text { situations, until } 2030\end{array}$ & & & \\
\hline & & 6.2 & $\begin{array}{l}\text { Achieve universal and equitable access } \\
\text { to safe and affordable drinking water for } \\
\text { all, until } 2030 \text {. }\end{array}$ & & & $\begin{array}{l}\text { Proportion of population that living in } \\
\text { household has sustainable drinking } \\
\text { water. }\end{array}$ \\
\hline \multirow{2}{*}{ Goal 7} & \multirow{2}{*}{$\begin{array}{l}\text { Ensure access } \\
\text { to affordable, } \\
\text { reliable, } \\
\text { sustainable and } \\
\text { modern energy } \\
\text { for all }\end{array}$} & 7.1 & $\begin{array}{l}\text { Ensure universal access to affordable, } \\
\text { reliable and modern energy services, } \\
\text { until } 2030 \text {. }\end{array}$ & & & $\begin{array}{l}\text { Proportion of population that living in } \\
\text { household has sustainable sources } \\
\text { energy for cooking }\end{array}$ \\
\hline & & 7.2 & $\begin{array}{l}\text { Increase substantially the share of } \\
\text { renewable energy in the global energy } \\
\text { mix, until 2030. }\end{array}$ & & & $\begin{array}{l}\text { Proportion of population that living in } \\
\text { household has sustainable sources } \\
\text { energy for lighting }\end{array}$ \\
\hline
\end{tabular}

Table 2. Value of standardization for 14 variables on TL-SDI.

\begin{tabular}{|c|c|c|c|c|c|c|}
\hline \multirow[b]{2}{*}{ No } & \multicolumn{6}{|c|}{ Standarization of value } \\
\hline & Variabel & Minum & Maximum & Average & $\underset{T L-S D I}{\operatorname{Minimum} \text { in }}$ & $\begin{array}{l}\text { Maximum } \\
\text { in TL-SDI }\end{array}$ \\
\hline 1 & Population 10 years and over literacy in Tetum & 45.9 & 96.2 & 71.0 & 0.0 & 100 \\
\hline 2 & $\begin{array}{l}\text { Population } 10 \text { years and over literacy in } \\
\text { Portuguese }\end{array}$ & 1.7 & 60.0 & 30.8 & 0.0 & 5 \\
\hline 3 & $\begin{array}{l}\begin{array}{l}\text { Population } 10 \text { years and over literacy in Bahasa } \\
\text { Indonesia }\end{array} \\
\end{array}$ & 13.6 & 77.2 & 45.4 & 0.0 & 7 \\
\hline 4 & Population 10 years and over literacy in English & 1.7 & 36.7 & 19.2 & 0.0 & 3 \\
\hline 5 & $\begin{array}{l}\text { Proportion of population } 12 \text { years and over have } \\
\text { complated basic education. }\end{array}$ & 12.8 & 77.9 & 45.3 & 0.0 & 70 \\
\hline 6 & $\begin{array}{l}\text { Proportion of population } 15-24 \text { years have } \\
\text { complated secondary education. }\end{array}$ & 3.9 & 60.9 & 32.4 & 0.0 & 5 \\
\hline 7 & $\begin{array}{l}\text { Proportion of population } 15-59 \text { years in } \\
\text { economic active have worked status. }\end{array}$ & 32.9 & 86.7 & 59.8 & 0.0 & \\
\hline 8 & $\begin{array}{l}\text { Proportion of population that living in Non-poor } \\
\text { household (with incme more than } 1.33 \$ \text { per capita } \\
\text { per day) }\end{array}$ & 13.3 & 80.2 & 46.7 & 0.0 & 70.0 \\
\hline 9 & $\begin{array}{l}\text { Proportion of population that living in household } \\
\text { has sustainable home ownership }\end{array}$ & 74.3 & 99.7 & 87.0 & 0.0 & 100.0 \\
\hline 10 & $\begin{array}{l}\text { Proportion of population that living in household } \\
\text { has sustainable liveable homes }\end{array}$ & 8.7 & 85.1 & 46.9 & 0.0 & $8 \mathrm{c}$ \\
\hline 11 & $\begin{array}{l}\text { Proportion of population that living in household } \\
\text { has sustainable sanitation facilities. }\end{array}$ & 19.5 & 98.9 & 59.2 & 0.0 & $100 . c$ \\
\hline 12 & $\begin{array}{l}\text { Proportion of population that living in household } \\
\text { has sustainable drinking water. }\end{array}$ & 30.9 & 99.3 & 65.1 & 0.0 & 100. \\
\hline 13 & $\begin{array}{l}\text { Proportion of population that living in household } \\
\text { has sustainable sources energy for cooking }\end{array}$ & 1.1 & 42.8 & 22.0 & 0.0 & 40. \\
\hline 14 & $\begin{array}{l}\text { Proportion of population that living in household } \\
\text { has sustainable sources energy for lighting }\end{array}$ & 20.8 & 98.1 & 59.5 & 0.0 & 100 \\
\hline
\end{tabular}

This study has used three dimensions, six goals, eleventh indicators, and fourteen variables, assisted by some previous research literature has produced TL-SDI values administrative posts in area municipality of Oecusse. Overall, there are TL-SDI values within administrative posts at the area municipality of Oecusse have differences. The illustrate value of TL-SDI of with Amoeba graphics for the administrative posts in the municipality of Oecusse has been done in Figure 1. The findings of this study have shown that the administrative post at the area municipality of Oecusse as an enclave has experienced un-equality of development, as 
evidenced by the lowest TL-SDI value which is the composition of low value of SCI and EnCI. The findings of this study are in accordance with the planning and implementation of development programs contained in TL-SDP 2011 - 2030 and Law RDTL no: 3/2014 regarding the formation of special zones in the municipality of Oecusse [10, 62, 63].

The findings of this study have strengthened the theory and narrative process about post- colonial and post-development by the geographer Simon1998; Radcliffe 2005; Raghuram and Madge 2006) [64], which assures that the administrative posts at the area municipality of Oecusse has a complex spatial pattern due to reconfiguration in post- colonial sovereignty entangled in reworking development and historically the area municipality of Oecusse people have commercial, cultural and demographic relations with the surrounding area and inseparable relations with the wider community and land of Timor-Leste as a nation and state.

Table 3. The value of summary ANOVA single factor for the analysis of comparison of TL- SDI.

\begin{tabular}{|l|r|r|r|r|}
\hline \multicolumn{2}{|l|}{ SUMMARY: Anova Single Factor } \\
\hline \multicolumn{1}{|c|}{ Groups } & \multicolumn{1}{l|}{ Count } & Sum & Average & Variance \\
\hline TL-SDI Non-migrant & 65 & 3845.4 & 59.2 & 51.7 \\
TL-SDI Migrant & 65 & 4266.1 & 65.6 & 53.5 \\
\hline
\end{tabular}

Table 4. The value of summary ANOVA single factor for the analysis of comparison of TL- SDI.

\begin{tabular}{|lr|r|r|r|r|r|}
\hline ANOVA & \multicolumn{1}{c|}{ Source of } \\
\hline $\begin{array}{l}\text { Variation } \\
\text { Setween Groups }\end{array}$ & \multicolumn{1}{c|}{ SS } & \multicolumn{1}{c|}{$d f$} & \multicolumn{1}{c|}{ MS } & \multicolumn{1}{c|}{ F } & P-value & F crit \\
\hline Within Groups & 6735.63 & 128 & 1361.64 & 25.88 & 0.00 & 3.92 \\
\hline Total & 8097.27 & 129 & & & & \\
\hline
\end{tabular}

Overall, this research has shown that there are significant differences in the achievement of TL-SDI scores between migrant and non-migrant populations, among the sixty-five (65) administrative posts in the Timor-Leste country which are incredibly significant. This is indicated by the calculated $\mathrm{F}$ statistics value greater than the $\mathrm{F}$ criteria in the single factor ANOVA table (Table 3 and Table 4). Likewise, this has also happened in the post administrative areas in the area municipality of Oecusse.

Table 5. Value of TL-SDI for the area of administrative posts include municipality of Oecusse

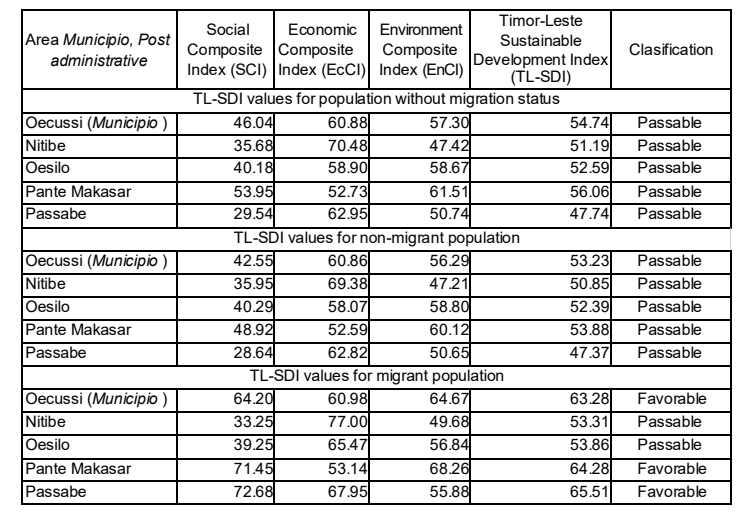

The findings of this study have shown, without distinguishing the migration status of its population, the area municipality of Oecusse has a TL-SDI of $54.74 \%$ entered good classification with a composition of the SCI $(46.04 \%)$, EcCI $(60.88 \%)$ and the value of the EnCI $(57.30 \%)$.

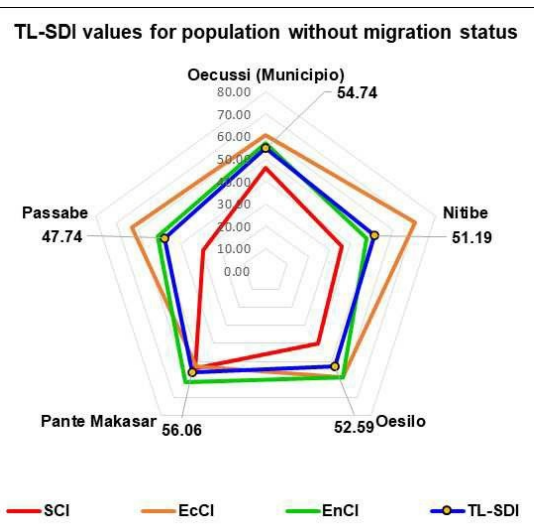

Fig. 1. The value of TL-SDI for population without distinguishing the migration status for area administrative posts include area municipality of Oecusse.

Without distinguishing the migration status of its population, in the municipality of Oecusse there are four administrative posts area that have an TL-SDI value of less than $61.00 \%$ or are classified passable (good enough). The lowest TL-SDI value without differentiating the migration status of the population in the administrative post Passabe (47.74\%), was formed values from the SCI (29.54\%) and EnCI (50.74\%) were lower thanother administrative posts in the area municipality of Oecusse.

The value of TL-SDI Figure 2 for population nonmigrant in the municipality of Oecusse has $53.23 \%$ entered passable classification with a composition of the SCI of $42.55 \%$, EcC Iof $60.86 \%$ and the value of the EnCI of $56.29 \%$. All area of the administrative posts which are under the municipality of Oecusse Ambeno have TL-SDI values below the standard value of $61 \%$ or passable classification. Thus, the results of research on the lowest TL-SDI value at the the municipality of Oecusse Ambeno that have occurred at the administrative post of Passabe (47.37\%). Some values that the composite index forms TL-SDI values in the administrative post of Passabe (47.37\%) are as follows: the SCI (28.64\%), EcCI (62.22\%) and EnCI (50.65\%).

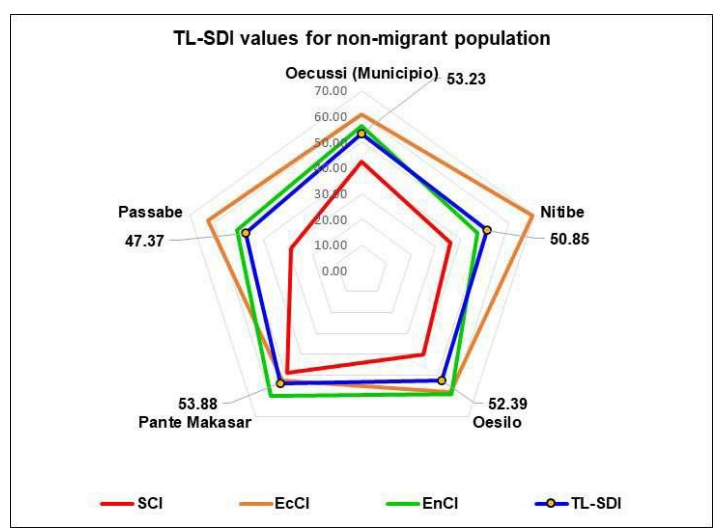

Fig. 2. The value of TL-SDI for non-migrant population for area administrative posts include the municipality of Oecusse. 
The results of this study have shown that the value of TL-SDI in the migrant population has reached $63.28 \%$ or above the standard value of $61.00 \%$ or in favorable or good classification. The high value of TLSDI in the the municipality of Oecusse has been formed from the composite index as follows: the SCI (64.20\%), EcCI $(60.91 \%)$ and EnCI $(64.67 \%)$. The results of research on the TL- SDI value in the highest migrant population at the the municipality of Oe-cusse has occurred at the Administrative post of Pasabe (65.51\%). The lowest value of TL-SDI for migrant population in Nitibe $(53.31 \%)$ has been formed from the composite index as follows: the SCI (33.25\%), EcCI (77.00\%) and EnCI (49.68 \%).

In this case was caused by the low value of SCI, this is evidenced by the low proportion of the population literacy of population aged 10 years and over who have Tetum (88.53\%), Portuguese (13.81\%), Indonesian (28.43\%), and English (43.22\%) languages. Besides that it is also caused by the low value of the proportion of the population aged $12 \mathrm{yr}$ and over who have completed basic education (15.19\%), and the lowest proportion of the population aged $15 \mathrm{yr}$ to $24 \mathrm{yr}$ who have completed senior secondary education only (3.91\%).

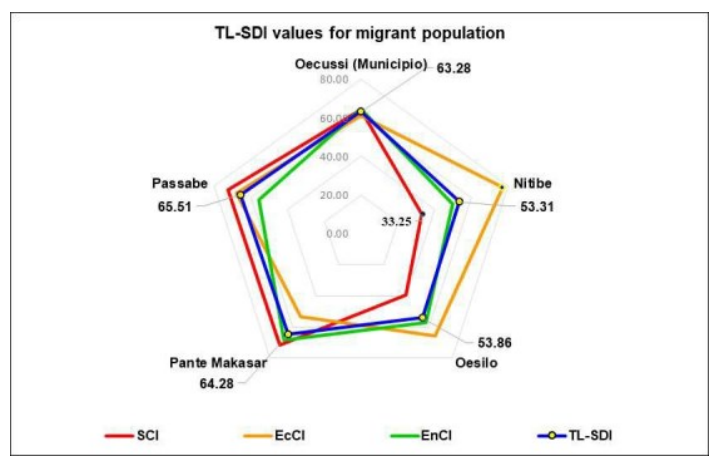

Figure 3: The value of TL-SDI for migrant population for area administrative posts include the municipality of Oecusse.

This result shows that those who have carried out internal migration into the administrative posts of Pasabe, Nitibe and Oesilo, because geographically the three administrative posts are in rural mountainous areas. These findings have shown that all three administrative posts have experienced internal migration of young people to the City for education and vice versa from the productive age population from urban areas with low skills they migrate to rural areas because of the urge to get a job, this results in "Brain drain "in rural and mountainous areas. These findings have strengthened the results of previous research from [65] as happened in the Switzerland country. Migrants and non- migrants (indigenous people) in the areas of Nitibe have shown evidence that they are experiencing uneven development "metageography", un-sustainable development, due to the geographical position as an enclave, especially in the social dimension measured from the low value of the proportion of primary and senior secondary education, and the low literacy as stated by Sidaway (2007) in Bainton [66].

The highest value of TL-SDI for migrant population in the Administrative post of Pasabe $(65.51 \%)$ has been formed from the composite index as follows: the SCI $(72.68 \%)$, EcCI $(67.95 \%)$ and EnCI $(55.88 \%)$. The TL-SDI value in the Pasabe area is still characterized by a low the EnCI (55.88 \%). In this case, the low of EnCI value is due to only $8.65 \%$ the population living in households with conditions for habitation and $2.02 \%$ of population have access to sustainable energy sources for cooking. Thus, migrants who enter and settle in this post administrative are migrants who experience unsustainable development because some of them live in uninhabitable homes with access to sustainable energy sources for cooking using log fire.

Nevertheless the results of this study have shown that the administrative post of Pante Makasar has been an urban area that has many facilities for better social, education, and economic, and environmental life, in fact it can only achieve the TL-SDI value for migrant population in the second highest ranking with value $64.28 \%$ in favorable or good classification. The value of TL-SDI in the administrative post of Pante Makasar has been formed from the composite index as follows: the SCI (71.45 \%), EcCI (53.14\%) and EnCI (68.28 \%). The findings of this study are interesting to study further is the low value of EcIC in Pante Makasar administrative post for both of population group migrant and nonmigrant. The administrative post of Pante Maksasar as urban area, usually have opportunities to increasing of education for young people, broader and more varied employment that's with the aim of reducing poverty [67, 68].

The results of this study at the municipality of Oecusse and each administrative post there are differences in the value of TL-SDI between migrant residents $(63.28 \%)$ and non-migrant residents $(53.23 \%)$, like in Figure 4. the difference value of TLSDI $10.05 \%$. The TL-SDI index value is highest in the non-migrant population in the administrative post of Pante Makasar (53.88 \%), due to its EcCI (52.59\%) and EnCI (60.12\%) and SCI (48.92\%). The TL-SDI value

is the lowest among non-migrant residents the administrative post of Pasabe $(47.37 \%$ ), due to its SCI $(28.64 \%)$, EcCI $(62.82 \%)$ and EnCI $(50.65 \%)$. The TL-SDI value for migrant population is highest in the administrative post of Pasabe (65.51\%), due to its EcCI $(67.95 \%)$ and EnCI $(55.88 \%)$ and SCI $(72.68 \%)$. The TL-SDI value is the lowest among migrant residents in the administrative post of Nitibe $(53.31 \%)$, due to its SCI $(33.25 \%)$, EcCI $(77.00 \%)$ and EnCI (49.68\%). This is consistent with the results that have been revealed by Ubilos (2012) [69] about how to measure human development in sustainability. The same opinion was also expressed by Reyers, et all (2017) [70] about the importance of focusing on selecting important variables in the measurement of sustainable development.

Overall, the TL-SDI value of the migrant population is different, the residents who have a lifetime of migration experience have made a more positive contribution to the TL-SDI value; this is evidenced that the migrant population group has a higher TL-SDI value compared to the non-migrant population. The results of this study have rejected (Ho) that there are differences 
in the value of TL- SDI between migrant and nonmigrant population.

Table 6. The different value of TL-SDI between migrant status administrative posts area in municipality of Oecusse.

\begin{tabular}{|l|r|r|r|}
\hline \multirow{2}{*}{ Area Municipio } & \multicolumn{3}{|c|}{ The values of TL-SDI } \\
\cline { 2 - 4 } & \multicolumn{1}{|c|}{ Migrant } & Non-migrant & Diffrences \\
\hline Oecussi (Municipio $)$ & 63.28 & 53.23 & 10.05 \\
\hline Nitibe & 53.31 & 50.85 & 2.46 \\
\hline Oesilo & 53.86 & 52.39 & 1.47 \\
\hline Pante Makasar & 64.28 & 53.88 & 10.40 \\
\hline Passabe & 65.51 & 47.37 & 18.13 \\
\hline
\end{tabular}

Differences Values of the TL-SDI between Migran and Non-migran

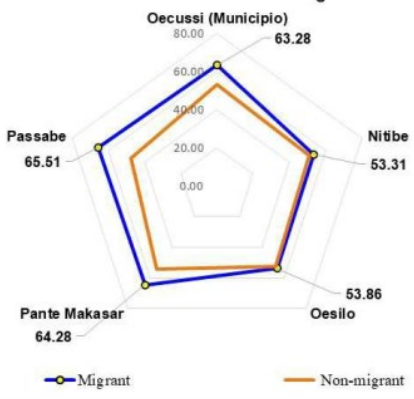

Fig. 4. The different value of TL-SDI in comparisons between non-migrant and migrant populations using Amoeba graphics.

This study also shows that development in the social dimension includes the achievement of primary and secondary education and literacy, the economic dimension of work status in productive age population and non-poor population, the environmental dimension with the proportion of the population living in livable homes complete with access to clean water and fulfillment sustainable energy sources obtained by migrant population groups prove that the process of migration (internal migration) that respects human rights has made a positive contribution to sustainable development in each region. The results of this study have strengthened the concept of the importance of measuring sustainable development in the population as the results of previous studies conducted by $[50,71,72]$.

\section{Conclusion}

The creation of an index of sustainable development (TL-SDI) for the country of Timor-Leste to have used six goals, eleventh indicators, and fourteen variables from the CPH-TL 2015 and the 2014 TLSLS. The area municipality of Oecusse as a municipality and administrative post, has produced TL-SDI for nonmigrant population $(53.23 \%)$ and without distingue of migrant status $(54.745 \%)$ the lowest values compared to other municipalities in the country of Timor- Leste, especially on SCI and EnCI values. The TL-SDI value internal migration among populations with different migrants and non- migrants. This study has answered the hypothesis that residents who have experienced a lifetime of internal migration have a positive influence and have a value of a sustainable development index that is higher than population who did not carry out internal migration.
Planning and evaluating the results of development in an area using the value of TL- SDI considering sustainable development indicators listed in the 2030 SDGs agenda is very possible. The techniques to build a sustainable development index can be done by modifying the composite index, preparation technique using population census data and combined with the most relevant surveys and adjacent years. Improving the implementation of the "Ensino Recorente" package program for reducing the proportion of illiterate populations and achieving basic education in the municipality of Oecusse is very important such as priority of development especially in the post administrative of Pasabe, Nitibe, and Oesillo.

\section{Abbreviation}

CHP-TL 2015: Census Household and Population Timor-Leste 2015. TL-SDI: Timor-Leste Sustainable Development Index. EcCI: Economic Composite Index. EnCI: Environment Composite Index. SCI: Social Composite Index. TL-SLS 2014: Timor-Leste Standard Living Survey 2014. SAROA: Special Administrative Region of Oecusse Ambeno Atauro. TL-SDP 2011 2030: Timor-Leste Strategic Development Plan 2011 2030

\section{Declaration}

Author contributions: All authors conducted fieldwork and contributed text segments to the manuscript. The final version of the manuscript was developed interactively, with all authors actively involved.

Conflicts of Interest: The authors declare that we have not complying and conflict of interests.

Availability of data and material: The data of $\mathrm{CPH}-$ 2015 and TL-LSL2014 that supporting in the conclusion of this article. Any questionnaires regarding this data may be direct to corresponding author.

Consent to the publication in the IEEE Xplore Digital Library or E3S Web of Conferences.

Ethics approval and consent to participate

Open Access

The author would like to grateful for supervisor Pak Kamdi and Ibu Rum, and to the ICST-UGM2020 for their many helpful, receipts, comment, and suggestion to this article. We would like to acknowledge to Marcos, Rose, Nina, two anonymous reviewers and the editors for their critical comments on earlier versions of this manuscript. We special thank also for financial support from Sustainable Development Research Program by Matenek Kmanek Foundation (grant number 26042017).

\section{References}

1. United Nations, Resolution adopted by the General Assembly on 25 September 2015. Transforming our world: the 2030 Agenda for Sustainable Devleopment., 70/1: 1-35 (2015).

2. United Nations, Transforming our world: The 2030 Agenda for Sustainable Development, New York, (2015). 
3. N. Molyneux, G.R. Cruz, R. Williams, R. Andersen, Ambio, 41,8: 301-318 (2012).

4. H. Bossel, Indicators for Sustainable Development: Theory, Method, Applications. A Report to the Balaton Group. Winnipeg, Manitoba, Canada: International Institute for Sustainable Development, (1999).

5. The World Bank Group, World Development Indicators 2017. Washington DC, (2017).

6. NSD and UNFPA Timor-Leste, Analytical Report on Migration and Urbanization, Dili Timor-Leste, (2012).

7. UNDESA, Manual VI Methods of Measuring Internal Migration, Population. New York: United Nations, (1970).

8. UNDESA, Principles and Recommendations for Population and Housing Censuses Revision 2, New York: UN-DESA (2008).

9. DGE-MOF, Household Questionnaire, Population and Housing Census 2015 Timor-Leste, July. DGEMOF, Dili Timor-Leste, p. 1-11, (2015).

10. Government of Timor-Leste, Snapshot of The Sixth Constitutional Government Mandate (2015 -2017), Dili, (2017).

11. L.S.M. Yoder, J. Southeast Asian Stud., 47,2: 281303 (2016).

12. L.S.M. Yoder, State, Soc. Gov. Melanes. Br. 2016/5, 5:2015-2016 (2016).

13. S.E. Purwatiningsih, A Measurement of Sustainable Development Index for Timor-Leste Country, Yogyakarta, Indonesia, (2020).

14. The World Bank, Water Supply and Sanitation in Timor-Leste: Turning Finance into Services for the Future, Dili Timor-Leste, (2014).

15. F. Laczko, Migration Indicators and The Post-2015 SDGs, Geneva, 2015.

16. P.Z. Espina, N.S. Arechavala, Soc. Indic. Res., 111, $1: 1-23(2013)$.

17. F. Giambo, E. Vassalo, Soc. Indic. Res., 116, 1:269-293 (2014).

18. R. Axelsson et al., Ambio, 42, 2:1- 15 (2018).

19. D. Cook, N.M. Saviolidis, B. Davíðsdóttir, L. Jóhannsdóttir, S. Ólafsson, Ecol. Indic., 74:463478 (2017).

20. A. Rodriguez, An Assessment Technique for Sustainability: Applying the IMAGINE Approach to Software Systems, Munchen, (2012).

21. J.C. Cuaresma, W. Lutz, Vienna Yearb. Popul. Res., 13,2015: 241-261 (2015).

22. J. Shen W. Xu, China Rev., 16, 3: 1-7 (2018).

23. UNFPA, Population Matters for Sustainable Development, New York, (2012).

24. UNFPA, Programme of Action of the International Conference on Population Development, 20th Anniv., September 1994. New York: United Nations Population Fund, (2014).

25. E.W. Sanderson, M. Jaiteh, M.A. Levy, K.H. Redford, A.V. Wannebo, G. Woolmer, Bioscience, 52,10: 891- 904 (2002).

26. W. Zhong-gen, L. Yu-zhou, Z. Ming- hua, X. Jun, J. Integr. Agric., 13, 1: 195-206 (2014).
27. M. Herrmann, J.M. Guzman, D. Schensul, Population Matters for Sustainable Development, (2012).

28. M.H. Rodriguez, J. Lat. Am. Geogr., 12, 2: $193-$ 219, (2013).

29. M.E. Kahn, J. Econ. Lit., 53, 3: 654-666, (2015).

30. A.J. Mturi, K. Fuseini, South. African J. Demogr., 17, 1:199-246 (2016).

31. B. Yang, T. Xu, L. Shi, J. Clean. Prod., 141: 868880 (2017).

32. H. Bossel, Indicators for Sustainable Development : Theory, Method, Applications, A Report to the Balaton Group. Winnipeg, Manitoba: International Institute for Sustainable Development, (1999).

33. G.H. Brundtland, Our Common Future: Report of the World Commission on Environment and Development, United Nations Comm., 4, 1: 300 (1987).

34. United Nations, Transforming our world: the 2030 Agenda for Sustainable Development, New York, (2015).

35. M. Awumbila, Drivers of Migration and Urbanization in Africa: Key Trends and Issues, New York, (2017).

36. H. de Haas, Int. Migr. Rev., 44, 1: 227-264 (2010).

37. J.M. Harris, Basic Principles of Sustainable Development, Tufts Univ., June, p. 26, (2000).

38. P.R. Voss, South. Demogr. Assoc., 26, 1: 457-467 (2007).

39. J. Hawkins, The Four Approaches to Measuring Wellbeing, In: Measuring and Promoting Wellbeing, D. Trewin, A. Podger, Eds. ANU Press (2014), 191-208.

40. F. Blancas, I. Contreras, R.J. Hurtado, J. Oper. Res. Soc., 64, 5: 668-678 (2013).

41. A.Z. Hamedani, Methodology And Statistical Analysis of Sustainable Transportation Criteria for Certification Systems, Wuppertal University, (2014).

42. B.J.E. Brink, F. Colijn, The Amoeba Approach: Quantitative Description and Assesment of Ecosystems, Netherland, (2013).

43. J. Kondyli, Environ. Impact Assess. Rev., 30,6:347-356 (2010).

44. M. Nardo, M. Saisana, A. Saltelli, S. Tarantola, A. Hoffman, E. Givannini, Handbook on Constructing Composite Indicators: Methodology and User Guide. OECD and JRC-EC, (2008).

45. D. Krajnc, P. Glavič, Resour. Conserv. Recycl., 43, 2:189-208 (2005).

46. Kementrian Pemberdayaan Perempuan dan Perlindungan Anak, Indeks Komposit Kesejahteraan Anak Kabupaten/Kota 2015. Jakarta: Kementerian Pemberdayaan Perempuan dan Perlindungan Anak, 2015.

47. E. Ravenstein, J. Stat. Soc. London, 48, 2: 167-235 (1885)

48. E.S. Lee, Demography, 3,1:47-57 (1966).

49. J.H. Relethfrord, J. Hum. Biol., 58,5:801-815 (1986)

50. R. Skeldon, International Migration, Internal Migration, Mobility and Urbanization: Towards 
More Integrated Approaches, September, 1-11 (2017).

51. UNDESA, Handbook on Population and Housing Census Editing, Revision Statistics Division UNDESA, (2010).

52. P. Myat Thu, Displacement and Informal Repatriation in a Rural Timorese Village, in A New Era?, S. Ingram, L. Kent, and A. McWilliam, Eds. ANU Press., 2015, 251-263 (2015).

53. D. Chakraborty, Migration and Urban Informal Sector: A Study in Wast Bengal, University of Burdwan, Burdwan, (2014).

54. J. Hagen-Zanker, Why do People Migrate? A Review of the Theoretical Literature, Maastrich Netherlands, (2008).

55. I.B.M. Astawa, J. Ilm. Ilmu Sos., 2, 1: 10-20 (2016). [in Bahasa Indonesia].

56. B.U. Eze, Int. J. Res. Environ. Stud., 3, 109-119, (2016).

57. G. Hugo, L. Dissanayake, The Process of Sri Lankan Migration to Australia Focusing on Irregular Migrants Seeking Asylum, in A Long Way to Go, M. McAuliffe and K. Koser, Eds. Canbera: ANU Press. 2017, 197-226 (2017).

58. UNDESA, Principles and Recommendations for Population and Housing Censuses - Revision 3, Edition 3., 3, March. New York: UN Statistics, (2008).

59. A. Rogers, J. Raymer, J. Popul. Res., 22,1:1-19 (2005).

60. Kementerian Desa PDTT, Indeks Desa Membangun 2015, Jakarta, (2016).

61. J. Sachs, SDG Index \& Dashboards, A Global Report, (2016).

62. Government of Republic of Timor- Leste, TimorLeste Strategic Development Plan 2011 - 2030, VERSION SU. Dili Timor-Leste: Palacio do Governo, (2011).

63. Presidencia da Conselho de Ministros RDTL, Program of the Sixth Constitutional Government 2015-2017, Dili Timor-Leste, (2015).

64. J.D. Sidaway, R. Geogr. Soc., 39,3:331- 339 (2007).

65. H. Mayer, A. Habersetzer, R. Meili, Sustain., 8, 8 (2016).

66. N. a. Bainton, Migrants, Labourersand Landowners at the Lihir Gold Mine, Papua New Guinea, in Large-scale Mines and Local-level Politics, no. October, C. FILER and P.-Y. LE MEUR, Eds. ANU Press. (2017), 2017.

67. I. Awad, P. Wickramasekara, P. Taran, International labour migration. A rights-based approach. (2010).

68. R. Black, J. Sward, Munich Pers. RePEc Arch., 19222:1-42, (2009).

69. J.B. Ubilos, Univ. Basqu. Coutry Spain, 111:437484, (2012).

70. B. Reyers, M. Stafford-Smith, K.H. Erb, R. J. Scholes, O. Selomane, Curr. Opin. Environ. Sustain., 26-27:97- 105 (2017).

71. W. Lutz, Population, Education and the Sustainable Development Goals, in Wittgenstein
Center for Demographhy and Global Human Capital., p. 27, (2016).

72. U.R. Ozkan,S. Schott, Soc. Indic. Reseach, 114,3: 1259-1283 (2013). 